\title{
DESIGN AND COMPARATIVE ANALYSIS OF DC-DC BOOST AND SINGLE-ENDED PRIMARY-INDUCTANCE CONVERTER CONVERTERS USING SOLAR POWERED MAXIMUM POWER POINT TRACKING ALGORITHMS
}

\author{
${ }^{1}$ Thulasiyammal, C. and ${ }^{2}$ S. Sutha \\ ${ }^{1}$ Department of EEE, The Kavery Engineering College, Salem, Tamil Nadu, India \\ ${ }^{2}$ Department of EEE, University College of Engg, Anna University, Panrutti, Tamil Nadu, India
}

Received 2014-01-01; Revised 2014-01-23; Accepted 2014-04-24

\begin{abstract}
This study provides a comprehensive review of the Maximum Power Point Tracking (MPPT) techniques applied to Photovoltaic (PV) power system. Also this study presents a comparative study between three most fashionable techniques such as Incremental conductance (Inc) algorithm and Perturb and Observation (P\&O) algorithm and fuzzy logic controller. These three techniques have been applied to converters such as Boost and SEPIC for analyzing the performance in various climatic conditions of $\mathrm{PV}$. The analysis of each technique with converters has been carried out by using MATLAB/simulink software. From the results few comparisons has been made and found that the boost converter with Incremental conductance algorithmic technique offered best and optimum results when compared with other techniques. This PV system can supply the maximum power to the load at all times due to which the entire PV system operates with maximum efficiency and produces its maximum power.
\end{abstract}

Keywords: Photovoltaic Array, Maximum Power Point Tracking (MPPT) Algorithms, P\&O, INC, Fuzzy Logic Controller, Boost Converter and Sepic

\section{INTRODUCTION}

Due to the growing demand on electricity, the limited stock and rising prices of conventional sources (such as coal and petroleum), Photovoltaic (PV) energy be-comes a promising alternative as it is universal, freely available, environment friendly and has less operational and maintenance costs (Subudhi and Pradhan, 2013). The Solar energy is a renew-able, inexhaustible and ultimate source of energy. If it is used in a proper way, it has a capacity to fulfill numerous energy needs of the world. The power from the sun intercepted by earth is approximately $1.8 \times 10^{11} \mathrm{MW}$ (Barreto et al., 2014). PV module represents the fundamental power conversion of PV module depends on the solar isolation, the cell unit of a PV generator system. The output characteristics

temperature and output voltage of PV module. Since PV module has nonlinear characteristics, it is necessary to model it for the design and simulation of Maximum Power Point Tracking (MPPT) for PV system applications (Belhadji and Bacha, 2013).

Therefore, controlling Maximum Power Point Tracking (MPPT) for the solar array is essential in a PV system (Chang and Kuo, 2013). A PV's Maximum Power Point (MPP) varies with solar insulation and temperature. Its V-I and V-P characteristic curves specify a unique operating point at which maximum possible power is delivered (Bianconi et al., 2013).

Therefore, controlling Maximum Power Point Tracking (MPPT) for the solar array is essential in a PV system (Chang and Kuo, 2013). A PV's Maximum Power Point (MPP) varies with solar insulation and Corresponding Author: Thulasiyammal, C., Department of EEE, The Kavery Engineering College, Salem, Tamil Nadu, India 
temperature. Its V-I and V-P characteristic curves specify a unique operating point at which maximum possible power is delivered (Bianconi et al., 2013). At the MPP, the PV operates at its highest efficiency. In general, a power source is operated in conjunction with a DC-DC power converter (boost and sepic), whose duty cycle is modulated in order to track the instantaneous MPP of the PV source (Hsieh et al., 2012).

Several methods and controllers have been widely developed and implemented to track the MPP. In the last years researchers and practitioners in PV systems have presented survey or comparative analysis of MPPT techniques. The various MPPT techniques are Perturb and Observe (P\&O) method (Chang and Kuo, 2013), Incremental Conductance (IC) method (Karthika and Rathika, 2012), Artificial Neural Network method, Fuzzy Logic method (Takun et al., 2012), Constant Voltage, Three Point weight Comparison, short Current Pulse, Open Circuit Voltage, the temperature method. In MPPT, most control schema use the $\mathrm{P} \& \mathrm{O}$ technique because it is easy to implement. But the oscillation problem is unavoidable (Kachhiya and Lokhande, 2011). An Incremental Conductance (INC) MPPT method that is implemented by detecting the harmonic components of the PV module voltage and current was first proposed to track accurately the peak power of PV systems that are subjected to random variations in isolation. Grid voltage stability enhancement using photovoltaic based static synchronous compensator has been discussed (Mayilvaganan et al., 2013).
Hence, in this study a P\&O and INC MPPT technique and fuzzy logic based MPPT technique is pro-posed (Salah and Ouali, 2010). Mechanical type of single axis tracking method is discussed using microcontroller (Thulasiyammal and Shylaja, 2008). These maximum power point techniques are faster and also it can minimize the voltage fluctuation after MPP has been recognized. The circuit diagram of photovoltaic system is shown Fig. 1. The MPPT algorithms have been designed using MATLAB functional block system.

\section{PHOTOVOLTAIC MODULE AND ARRAY MODEL}

The model of solar cell can be categorized as p-n Semiconductor junction. When exposed to light, the DC current is generated. As known by many researchers, the generated current depends on solar irradiance, temperature and load current. The typical equivalent circuit of PV cell is shown in Fig. 2. The electrical parameters of the PV panel are shown in the Table 1.

Table 1. PV panel parameters rating

\begin{tabular}{ll}
\hline PV temperature & $25^{\circ} \mathrm{C}$ \\
\hline $\mathrm{O} / \mathrm{P}$ voltage & $12 \mathrm{~V}$ \\
$\mathrm{O} / \mathrm{P}$ current & $0.5 \mathrm{~A}$ \\
$\mathrm{O} / \mathrm{P}$ power & $6 \mathrm{~W}$ \\
\hline
\end{tabular}

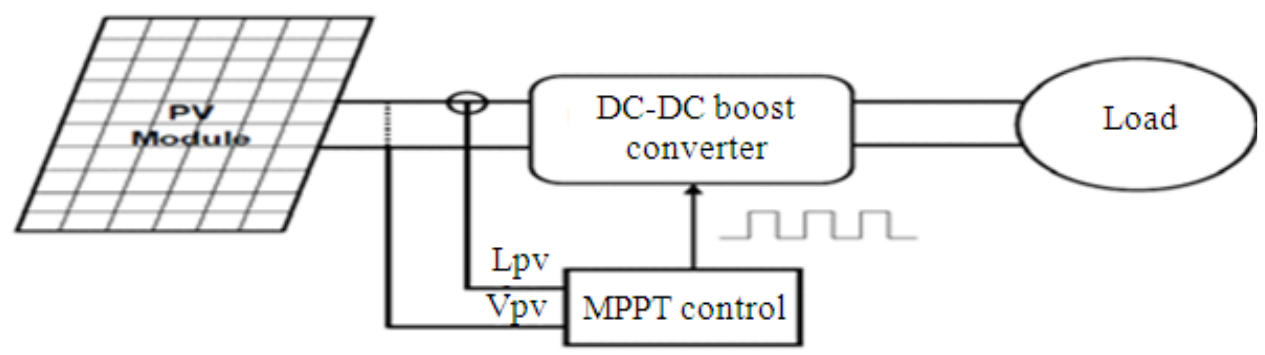

Fig. 1. Typical diagram of MPPT in a PV system

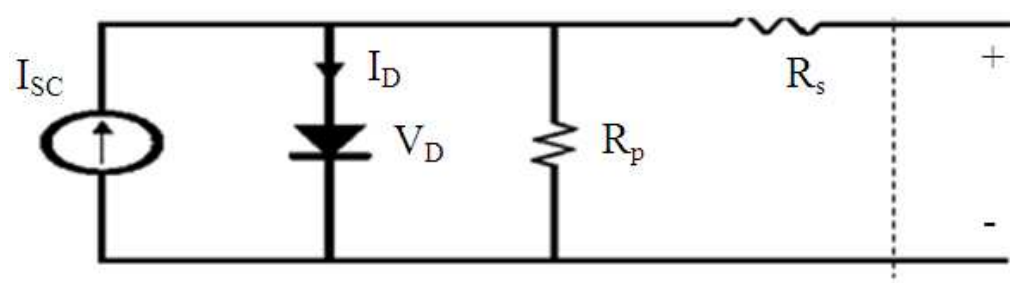

Fig. 2. Typical circuit of PV solar cell 
The basic equations describing the I-V characteristic of the PV model are given in the following equations:

$$
\begin{aligned}
0 & =I s c-I d^{(-V d / V t)}-I p v \\
I d & =I o\left(e^{\mathrm{Vd} / \mathrm{Vt}}-1\right) \\
\mathrm{Vpv} & =\mathrm{Vd}-\mathrm{Rs} \text { Ipv }
\end{aligned}
$$

Where:

$\mathrm{IPV}=$ The cell current $(\mathrm{A})$

ISC $=$ The light generated current $(\mathrm{A})$

$\mathrm{I}_{\mathrm{D}} \quad=$ The diode saturation current $(\mathrm{A})$

Rs $=$ the cell series resistance. $(' \Omega)$

$\mathrm{R}_{\mathrm{p}}=$ The cell shunt resistance $(\Omega)$

$\mathrm{Vd}=$ The diode Voltage $(\mathrm{V})$

$\mathrm{Vt}=$ The temperature Voltage $(\mathrm{V})$

$\mathrm{Vp}=$ The cell voltage $(\mathrm{V})$

\section{MAXIMUM POWER POINT TRACKING TECH-NIQUES}

The output power of the solar PV module changes when the changes in direction of the sun, change in solar isolation level and change in temperature. Here the modified and also the most common algorithms of
$\mathrm{P} \& \mathrm{O}$ and the incremental conductance methods have been described. The modified Incremental Conductance method offers the main advantage of providing high efficiency, voltage under rapidly changing atmospheric conditions, so it has been employed in the proposed model. However in this study another MPPT algorithm such as modified P\&O could be used to formulate the comparative analysis.

\subsection{Modified Perturb and Observation Technique}

One of the most simple and popular techniques of MPPT is the P\&O technique. The main concept of this method is to push the system to operate at the direction in which the output power obtained from the PV system will be increased. Following Fig. 3 shows the flowchart of the $\mathrm{P} \& \mathrm{O}$ which describes the change of output power according to the changes of the PV panel parameters.

If the change of power and voltage differentiation is greater than zero, the system will keep the direction of the incremental power (increase or decrease the PV power) as the same direction and if the change is lesser than, the system will change the direction of incremental power command to the opposite direction.

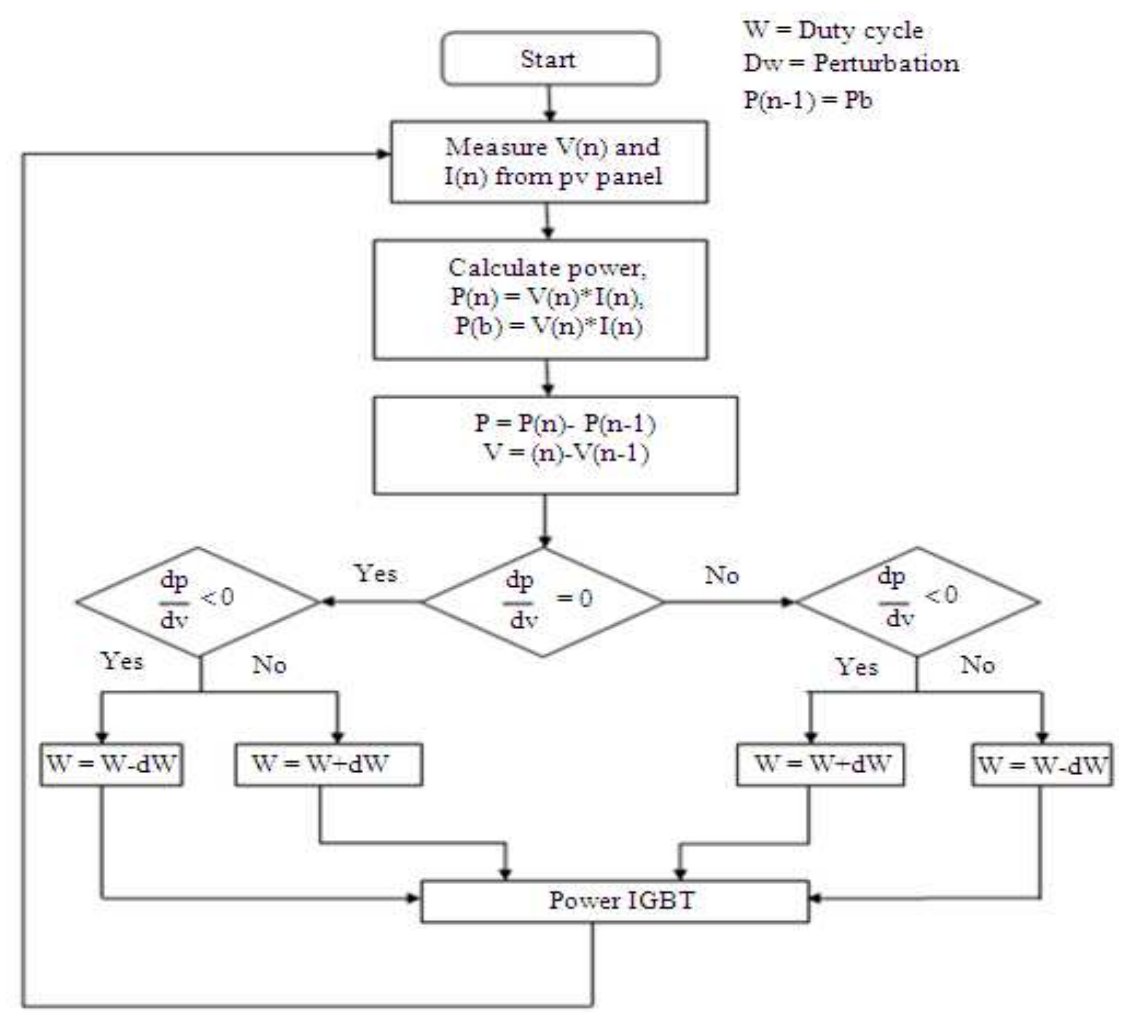

Fig. 3. Flow chart of the $\mathrm{P} \& \mathrm{O}$ method 
In existing method, measured voltage and current values changes only in minimum level without oscillations. But it produces some error. But in the modified method measured voltage and current values changes in maxi-mum level without oscillations around the maximum power point. So that it reduces the output error in a maximum level.

This method works well in the steady state condition according to the solar irradiation and temperature conditions change slowly. However, the $\mathrm{P} \& \mathrm{O}$ method fails to track MPP when the atmospheric condition is rapidly changed.

\subsection{Modified Incremental Conductance Technique}

This method exploits the assumption of the ratio of change in output conductance is equal to the negative output conductance of instantaneous conductance. In existing method measured voltage and current value changes taking more number of step size. Since its circuit complicity it takes more computational time. Figure 4 shows the flow chart for modified INC method. In this modified measured voltage and current value changes taking less number of step size. The computational time is decreased due to slowing down of the sampling frequency.

Thus, MPP can be tracked by comparing the instantaneous conductance to the incremental conductance. It is the same efficient as $\mathrm{P} \& \mathrm{O}$, good yield under rapidly changing atmospheric conditions.

Here also the same perturbation size problem exists as like in the $\mathrm{P} \& \mathrm{O}$ method. But an attempt has been made to solve and increase the output power by using variable conductance technique. Step by step variation of conductance has been made by decrement and increment to track maximum power though the climatic conditions changes. For this method, the algorithmic circuit has been designed according to the flowchart using MATLAB software.

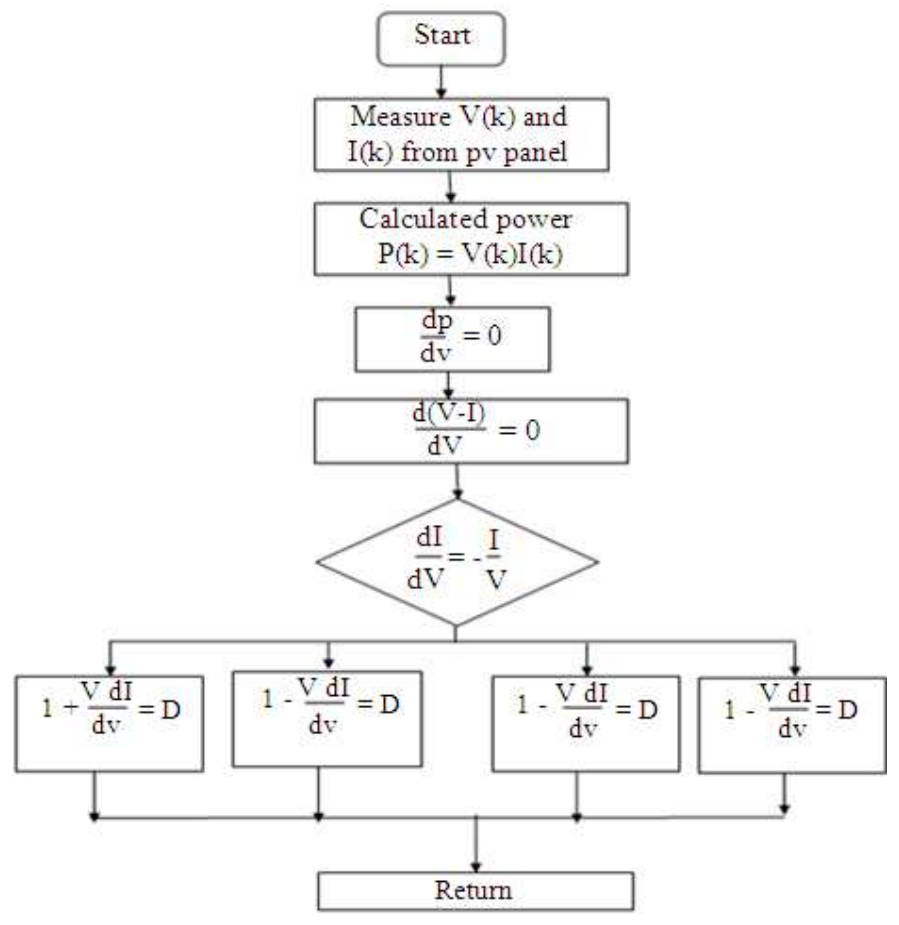

Fig. 4. Flow chart for INC method

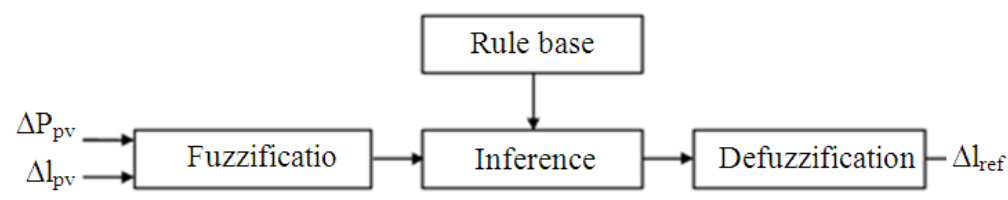

Fig. 5. Fuzzy logic controller 


\subsection{Modified Fuzzy Logic Controller Technique}

MPPT techniques by using Fuzzy Logic Control, gains several advantages like better performance, robust and simple in design. In addition to that this technique does not require the knowledge of the exact model of system. The main parts of FLC, fuzzification, rule-base, inference and defuzzification, are shown in Fig. 5.

Fuzzy logic is implemented to assist the conventional MPPT technique to obtain the MPP operating voltage faster and also it can minimize the voltage fluctuation after MPP has been recognized.

\section{PROPOSED MODEL OF THE SYSTEM}

In the proposed method three types of MPPT algorithms like Perturb and Observe (P\&O), Incremental Conductance (INC) and fuzzy logic control have been designed with DC-DC boost and Sepic converters. Here all the combinations of converters with algorithms have been modelled and simulated using MATLAB/SIMULINK software. Simulink model of the perturb and observation method with boost converter is shown in Fig. 6.
In DC-DC boost converter IGBT is used as a switching device for changing the duty cycle according to the change in output power from the SPV and MPPT output.

Simulink model of the perturb and observation method with sepic converter is shown in Fig. 7. The Single-Ended Primary-Inductance Converter (SEPIC) is a DC/DC-converter topology that provides a positive regulated output voltage from an input voltage. Sepic converter working operation is as buck-boost converter method. The duty cycle of this converter is varied according to the changes of the climatic conditions.

Figure 8 shows the modified Incremental Conductance (INC) method based on DC-DC boost converter technique. Figure 9 shows the modified incremental conductance (INC) method with SEPIC converter. When compared with $\mathrm{P} \& \mathrm{O}$ method, the Incremental conductance having output of higher voltage, power and efficiency. But working operation is smaller complex.

Figure 10 and 11 shows the modified fuzzy logic control method based on DC-DC boost converter and sepic converter techniques respectively. Both converters are simulated and compared their outputs.

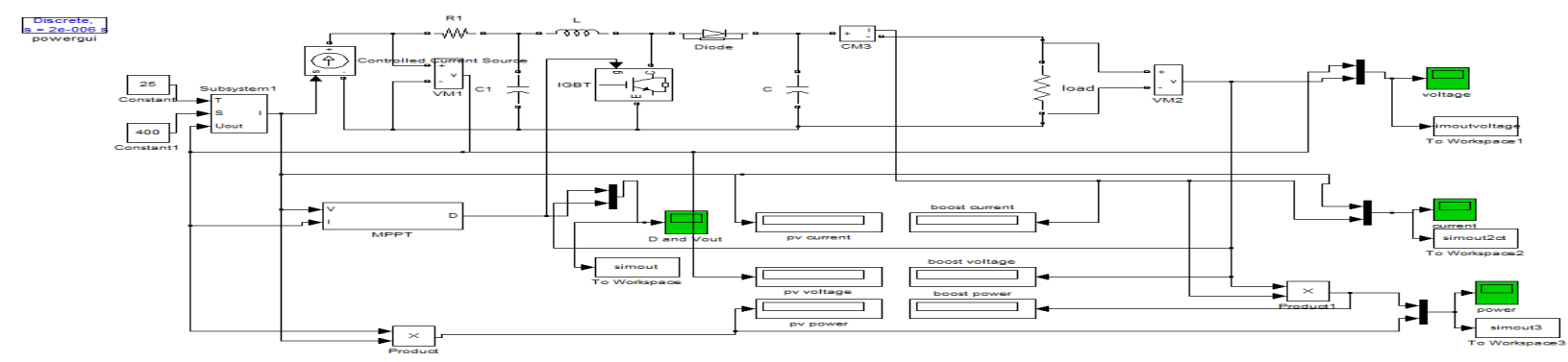

Fig. 6. Simulink diagram of perturb and observation method using boost converter

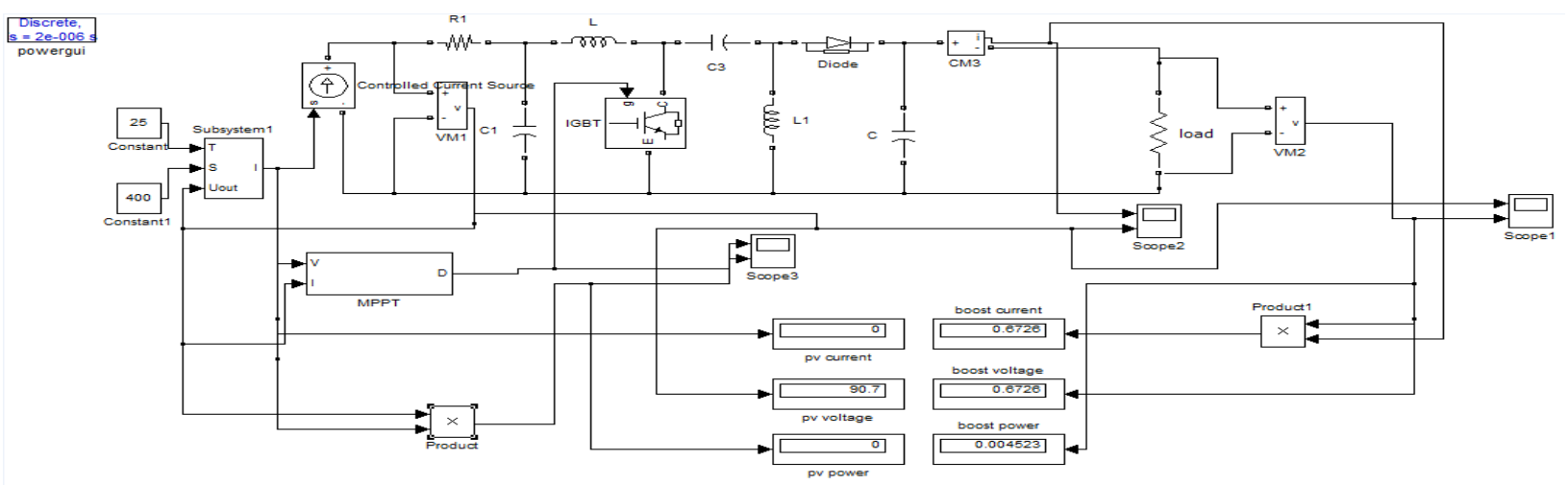

Fig. 7. Simulink diagram of perturb and observation method using Sepic converter 
Thulasiyammal, C. and S. Sutha / American Journal of Applied Sciences 11 (7): 1113-1122, 2014

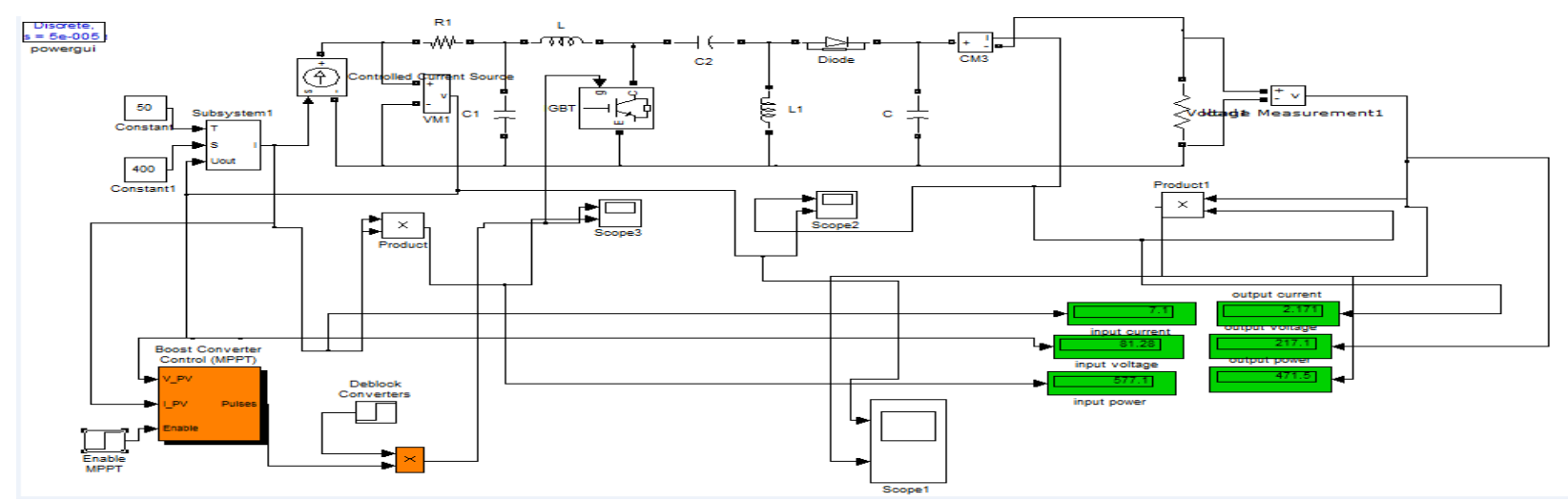

Fig. 8. Simulink diagram for incremental conductance using boost converter

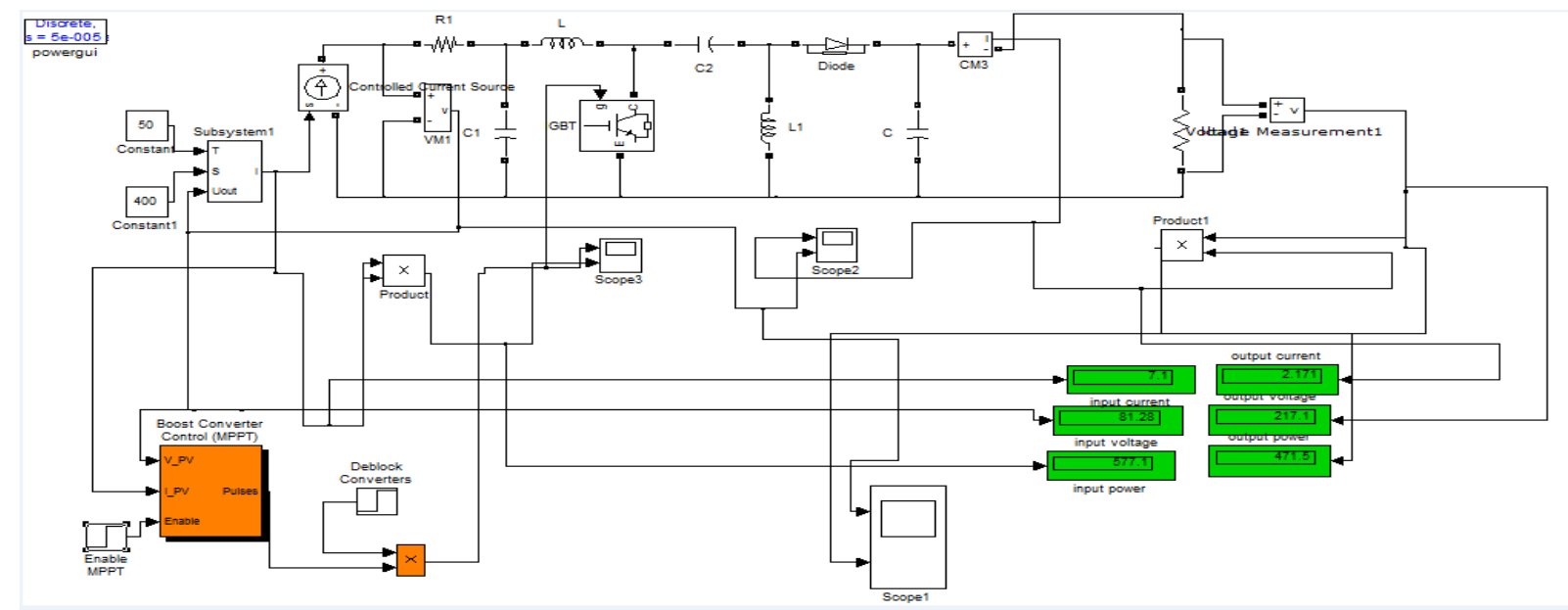

Fig. 9. Simulink diagram of incremental conductance with sepic converter

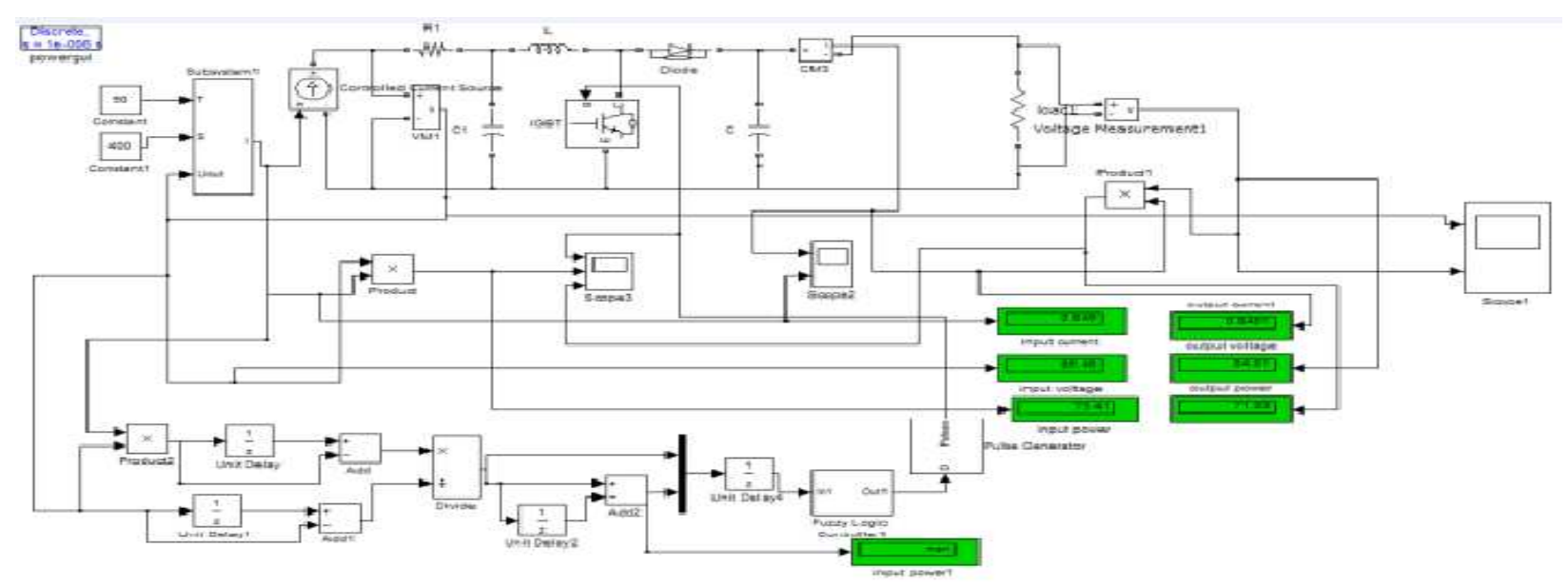

Fig. 10. Simulink diagram for fuzzy logic controller using boost converter 
The above six combinations have been simulated and their output voltage, current and power are compared. The output voltage, current, power of PV panel is given to boost and Sepic converters. Here to control the output of the PV panel the current controlled device is connected in boost and sepic converter circuit. The output characteristics of power, current, voltage are separately displayed to make comparison both for boost and sepic converters in the simulink diagram.

\section{RESULTS AND DISCUSSION}

All the simulation results for every converter have been recorded in order to compare these three algorithms with DC -DC boost and Sepic converters. Figure 12 and 13 shows the input and output power of Boost and SEPIC converters with respect to time for $\mathrm{P} \& \mathrm{O}$ algorithm.From this it can be judged that the maximum power is attained $73 \%$ in a very shorter time period and it is maintained only for fewer time duration in case of boost converter but the same maximum power is maintained with modest time period with oscillations.

Figure 14 and 15 shows the input and output power of Boost and SEPIC converters with respect to time for INC algorithm.According to the output waveform, the maximum output power can be reached $70 \%$ in a shorter period and it is maintained upto long duration in a boost converter with good conditions but the same power is attained with some oscillations for SEPIC converter. Figure 16 and 17 shows the input and output power of Boost and SEPIC converters with respect to time for fuzzy logic based algorithm. From this it can be analysed that the maximum power is attained only $30 \%$ in a very shorter time period and it is maintained for longer time duration using boost converter but in sepic it reaches $35 \%$ after longer time period.

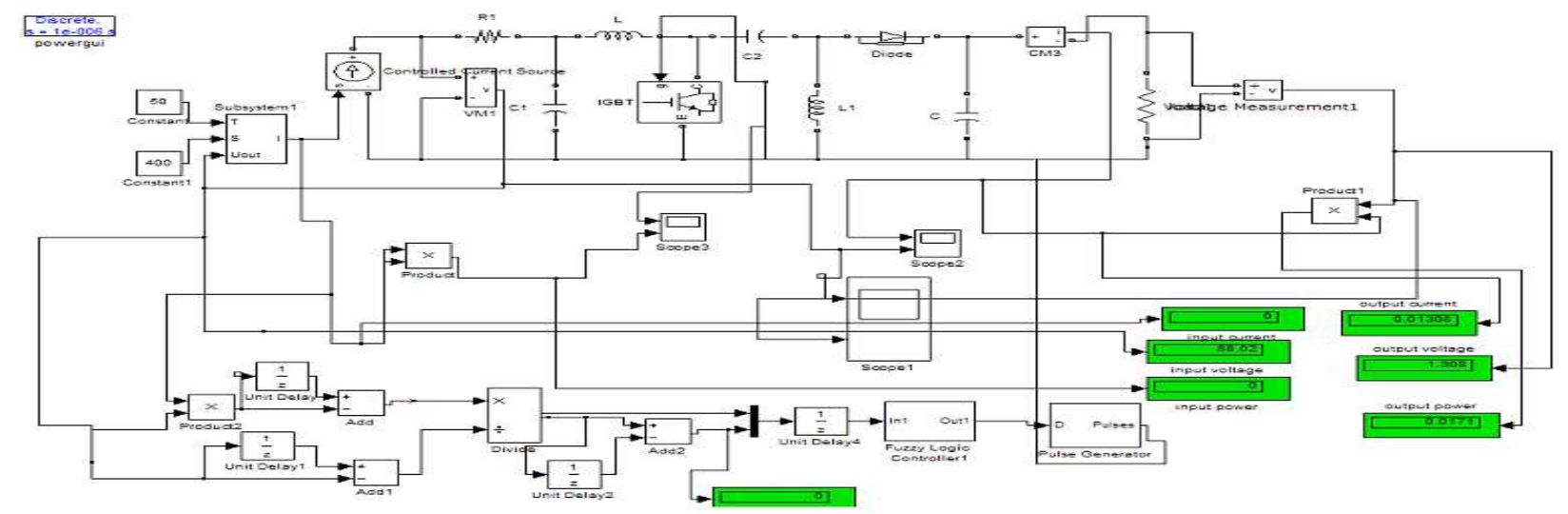

Fig. 11. Simulink diagram for fuzzy logic controller using sepic converter

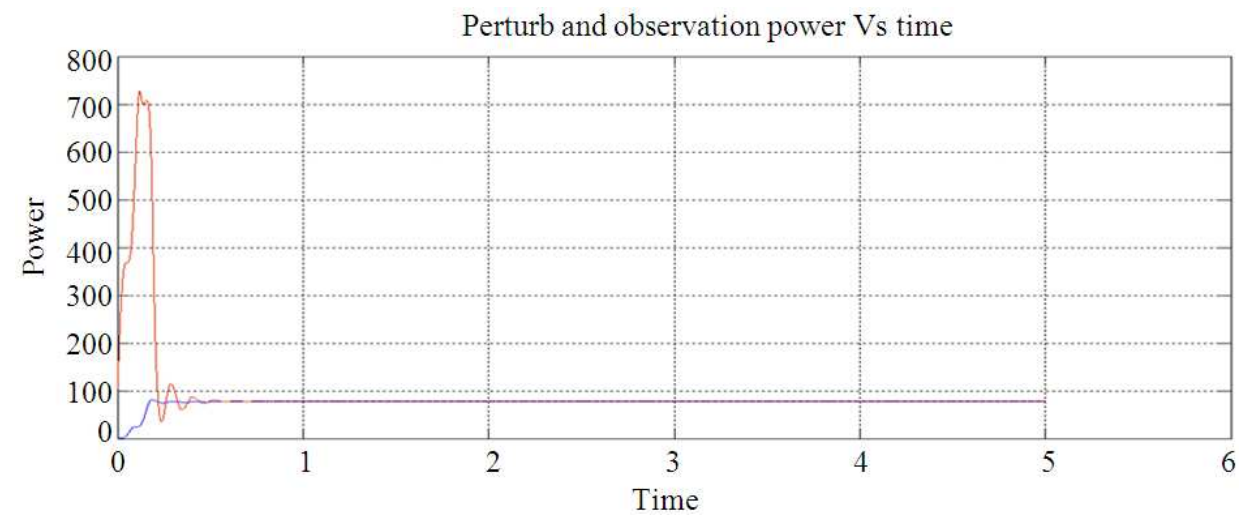

Fig. 12. Output power of $P \& O$ method using boost converter 
Thulasiyammal, C. and S. Sutha / American Journal of Applied Sciences 11 (7): 1113-1122, 2014

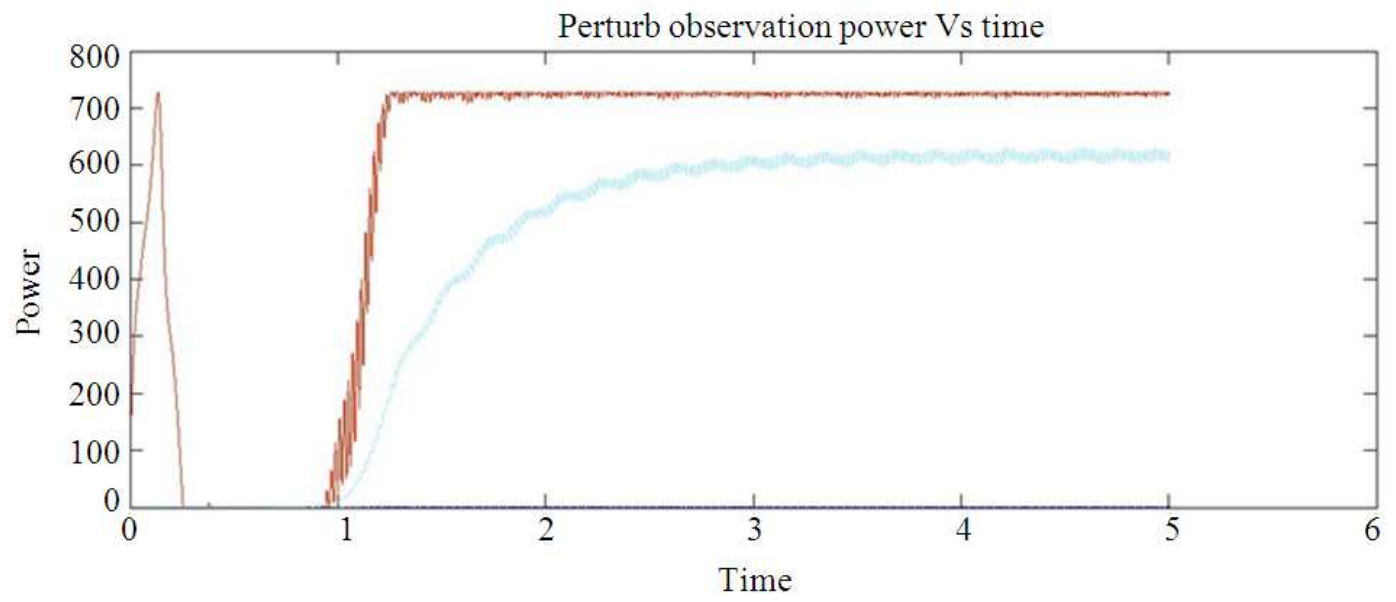

Fig. 13. Output power of $P \& O$ method using Sepic converter

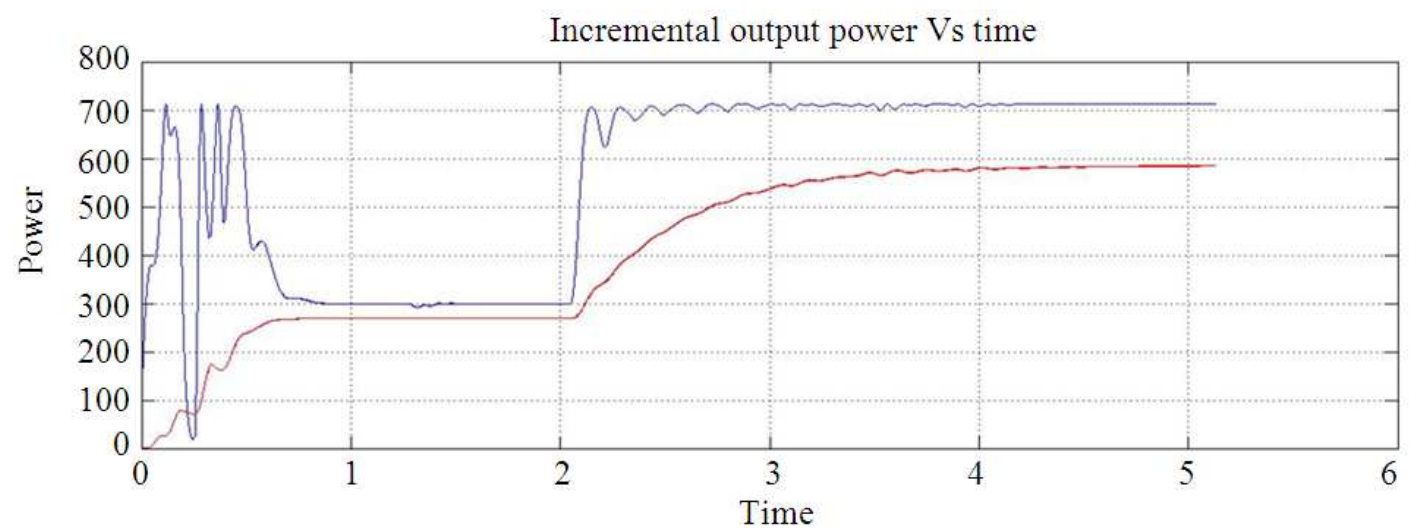

Fig. 14. Output power of incremental conductance method using Boost converter

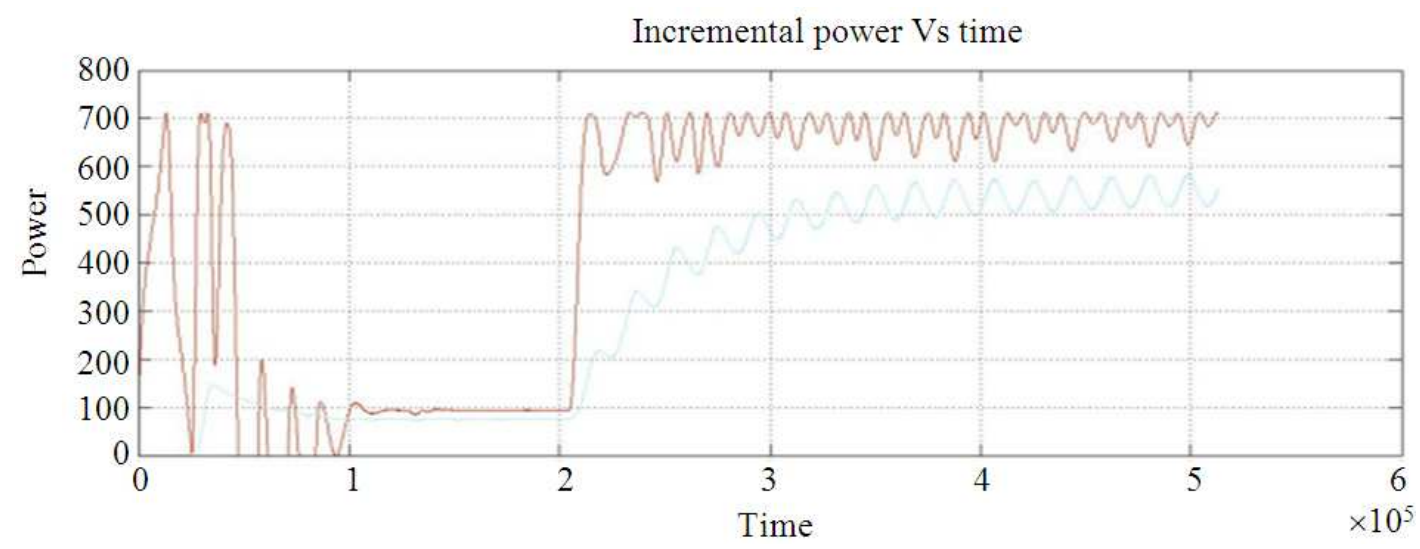

Fig. 15. Output power of incremental conductance method using sepic converter 


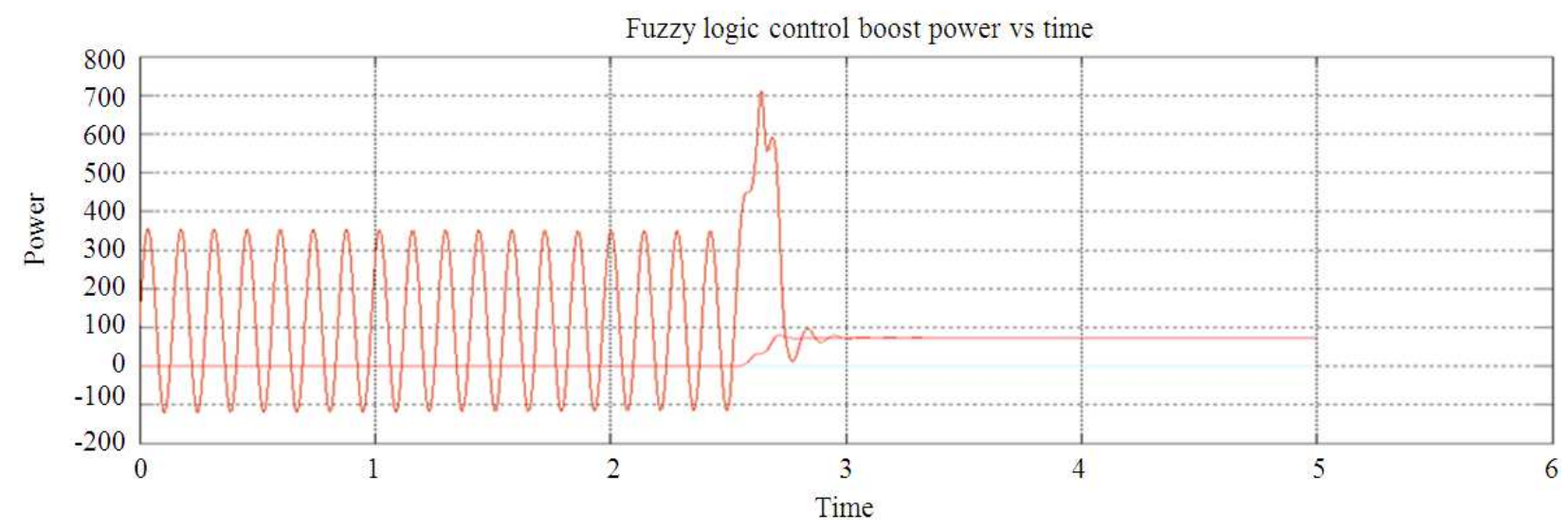

Fig. 16. Output power of fuzzy logic controller method using boost converter

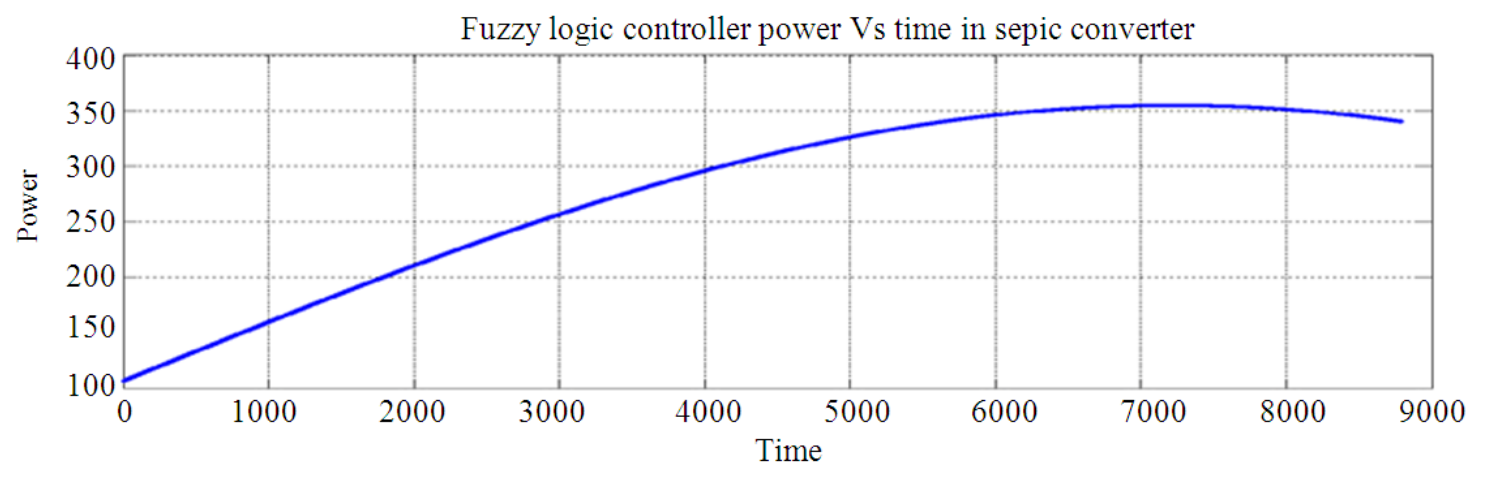

Fig. 17. Output power of fuzzy logic controller method using sepic converter

In this study it has been analyzed and found that the incremental conductance method using boost converter giving best results and maximum power output to the same value of input values when compared with other two MPPT techniques with DCDC boost and Sepic converters.

\section{CONCLUSION}

In general, the effectiveness of MPPT is theoretically defined as a ratio of the practical power output to the true maximum power value. In this study it has been presented a comparison among the different MPPT techniques for the PV system using perturb and observe (P\&O), Incremental Conductance (INC) using boosts and sepic converters and fuzzy logic control using boost converter. A high voltage gain boost and sepic converters has been presented in this study for getting improved outputs.

Also, it has been concluded that the proposed incremental conductance MPPT technique with boost converter could track the maximum power in faster rate when compared with the P\&O based MPPT technique and fuzzy logic control with boost converter and sepic converter. But by using INC MPPT controller with boost converter has the capability to track the maximum power than others and also it reduces the voltage fluctuation and improves the efficiency of the system.

\section{REFERENCES}

Barreto, L.H.S.C., P.P. Peixoto, D.S. Oliveira and R.N.A.L. Silva, 2014. High-voltage gain boost converter based on three-state commutation cell for battery charging using PV panels in a single conversion stage. IEEE Trans. Power Electron., pp: 150-158. DOI: 10.1109/TPEL.2013.2248023

Belhadji, L. and S. Bacha, 2013. Adaptive MPPT applied to variable-speed microhydropower plant. IEEE Trans. Energy Convers., 28: 34-43. DOI: 10.1109/TEC.2012.2220776 
Bianconi, E., J. Calvente, R. Giral, G. Petrone and C.A. Ramos-Paja et al., 2013. A fast currentbased MPPT technique employing sliding mode control. IEEE trans. Indust. Electron., 60: 11681178. DOI: 10.1109/TIE.2012.2190253

Chang, Y.C. and C.L. Kuo, 2013. Development and operational control of two-string maximum power point trackers in dc distribution systems. IEEE Trans. Power Electron., 28: 1852-1861. DOI: 10.1109/TPEL.2012.2210737

Hsieh, G.C., H.I. Hsieh, C.Y. Tsai and C.H. Wang, 2012. Photovoltaic power-increment-aided incremental-conductance mppt with two-phased tracking. IEEE Trans. Power Electron., 28: 28952911. DOI: 0.1109/TPEL.2012.2227279

Kachhiya, K. and M. Lokhande, 2011. MATLAB/simulink model of solar PV module and MPPT algorithm. Proceedings of the National Conference on Recent Trends in Engineering and Technology, May 13-14, B.V.M. Engineering College, V.V.Nagar, Gujarat, India.

Karthika, S. and P. Rathika, 2012. Fuzzy logic based maximum power point tracking designed for $10 \mathrm{kw}$ solar photovoltaic system. IJCSMR, 2: 1421-1427.
Mayilvaganan, A.B., S.S. Dash and V. Venkataramanan, 2013. Grid voltage stability enhancement using photovoltaic based static synchronous compensator. J. Comput. Sci., 9: 299-307. DOI: 10.3844/jcssp.2013.299.307

Salah, C.B. and M. Ouali, 2010. Comparison of fuzzy logic and neural network in maximum power point tracker for PV systems. Electric Power Syst. Res., 81: 43-50. DOI: 10.1016/j.epsr.2010.07.005

Subudhi, B. and R. Pradhan, 2013. A comparative study on maximum power point tracking techniques for photovoltaic power systems. IEEE trans. Sustainable Energy, 4: 89-98. DOI: 10.1109/TSTE.2012.2202294

Takun, P., S. Kaitwanidvilai and C. Jettanasen, 2012. Maximum power point tracking using fuzzy logic control for photovoltaic systems. Proceedings of the International Multi Conference of Engiveers and Computer Scientists, Mar. 16-18, Hong Kong.

Thulasiyammal, C. and R. Shylaja, 2008. An effective method of solar tracking system using microcontroller. J. Institution Eng. 